\title{
A Systematic Literature Review on the Academic and Athletic Identities of Student-Athletes
}

\author{
Andrea R. Steele, Fleur E. C. A. van Rens, and Rebecca Ashley \\ Murdoch University
}

\begin{abstract}
Academic and athletic identities are related to performance and wellbeing indicators in both the educational and sport domains, respectively. This paper presents a systematic literature review examining empirical research into the academic and athletic identities of student-athletes in dual (education and sport) careers. The 42 records identified in this review suggest that research on the academic and athletic identities of student-athletes has focused on the themes of: identity development, role conflict, career development and motivation, and student-athlete stereotypes. Future research directions are considered, including the need for mixed-methods and longitudinal assessments of academic and athletic identities to assess the dynamic nature of identity development, and to ascertain how these relate to future performance and wellbeing outcomes.
\end{abstract}

Keywords: identity, education, sport, talent development, dual careers

Identity is defined as one aspect of an individual's wider self-concept, encapsulating an individual's subjective assessment of who they are, and how they fit with their social world in relation to others (Brewer \& Gardner, 1996; Caza, Vough, \& Puranik, 2018). Identity is tied to appraisals of self-definition, self-worth, and self-esteem, and informs values and goal-related behaviors (Brewer, Van Raalte, \& Linder, 1993; Gecas, 1982). Identity salience refers to the commitment to, and subjective importance of an identity, relative to other self-identities, with highly salient identities more likely to be activated across contexts and to motivate behaviors aligned to that identity (Stets \& Burke, 2000; Stryker \& Burke, 2000). Salient self-identities are usually developed around key life roles, reflecting levels of commitment to, and investment in, those roles (Stryker \& Burke, 2000; Thoits, 1983). Performance of behaviors aligned with specific roles will serve to further strengthen related role identities (Terry, Hogg, \& White, 1999).

Globally, many elite and semi-elite athletes simultaneously participate in competitive sport and higher education (see Wylleman \& Lavallee, 2004). These athletes thus participate in dual careers in sport and education and are commonly referred to as 'student-athletes' in scientific literature (Ivarsson et al., 2015; Stambulova, 
Engström, Franck, Linnér, \& Lindahl, 2015; Stambulova \& Wylleman, 2015). Congruent with theories of relational identity-development (e.g., Stryker 1987), these student-athletes are thus predicted to develop domain-specific identities aligned with their roles as students and athletes.

Athletic identity specifically refers to the self-definition and meaning that is developed in relation to a role as an athlete and has been asserted to be central to the self-concept of athletes (Brewer et al., 1993). Athletic identity has been most commonly researched in the context of transitions that occur at times of athletic retirement (e.g., Grove, Lavallee, \& Gordon, 1997; Reifsteck, Gill, \& Labban, 2016; Ronkainen, Kavoura, \& Ryba, 2016; Smith \& Hardin, 2018), injury (e.g., Brewer, Cornelius, Stephan, \& Van Raalte, 2009; Green \& Weinberg. 2001), or performance set-backs (e.g., Brewer, Selby, Linder, \& Petitpas, 1999; Brown \& Potrac, 2009). Amongst (semi-)elite athletes, athletic identities have been found to increase in importance from childhood through to adolescence, as the demands of sport intensify (Houle, Brewer, \& Kluck, 2010). Further, athletic identity is positively associated with athletic role commitment and sporting success (Horton \& Mack, 2000). Therefore, a strong athletic identity is often considered desirable for aspiring and elite athletes (Williams \& Krane, 1993). However, individuals with a sole commitment to their sporting identity have an increased risk of experiencing burnout and psychological distress when retiring from their sports (Anderson, 2012; Horton \& Mack, 2000; Wylleman, Rosier, \& De Knop, 2015). Researchers suggest that the risk of identity foreclosure, referring to an over-commitment to a specific role and avoidance of behaviors to explore other role identities, is higher in sport compared to other domains because athletic identity is generally developed at a young age before other possible role identities are explored (Brewer \& Petitpas, 2017; Houle et al., 2010). From a life-span perspective, there is a high level of risk in exclusively investing in a highly specialized domain, such as sport, given that an unsuccessful or ending sporting career may leave the individual without more generalized skills to pursue alternative vocational domains (Schulz \& Heckhausen, 1996). For student-athletes, the pursuit of a university degree thus represents an opportunity to establish or strengthen a self-identity that is distinct from their athletic identity and to diversify their skill base (Schulz \& Heckhausen, 1996).

Academic identity refers to the self-meaning derived from one's role as a student and subsequent expectations on oneself derived from this role (Ewing \& Allen, 2017; Mortimer, Lam, \& Lee, 2015). The classroom environment provides a dynamic context in which the strength of an academic identity is continuously negotiated to meet role demands and the expectations of peers and teachers (DeCandia, 2014; Kaplan \& Flum, 2010; Hawkins, 2005; Swanson, Spencer, Dell-Angelo, Harpalani, \& Spencer, 2002). An academic identity positively predicts student motivation, goal-orientation, academic commitment, persistence, and successful performance in academic domains (Lairio, Puukari, \& Kouvo, 2013; Hejazi, Lavasani, Amani, \& Was, 2012; Osborne \& Jones, 2011), as well as guides decisions relating to the pursuit of future career paths (Swanson et al., 2002). 
A plethora of research has suggested that holistic athlete development, in which athletes are encouraged to participate in non-sporting life-domains, facilitates their wellbeing, provides them with long-term psychological and psychosocial advantages, as well as sets them up for viable alternative careers if their sporting endeavors are unsuccessful (see Henriksen, Stambulova, \& Roessler, 2010; Schinke, Stambulova, Si, \& Moore, 2018; Wylleman \& Lavallee, 2004; Wylleman \& Rosier, 2016). Yet, although there is reasonable understanding of athletic identity of athletes, and academic identity of students, how these identities co-exist and co-contribute to an overall sense of self in student-athletes is not as well understood (van Rens, Ashley, \& Steele, 2019; Yukhymenko-Lescroart, 2014). Understanding the development of salient self-identities in student-athletes will better equip practitioners in supporting holistic athletic development. Although commitment across multiple key roles may result in negative consequences, such as role and identity conflict (Stryker \& Burke, 2000), researchers have demonstrated that development of a multidimensional identity is positively associated with self-esteem, healthy psychological functioning, and wellbeing (Linville, 1985, Thoits, 1983). Concurrently engaging in both education and sport may enable student-athletes to remain invested in sport whilst engaging in wider self-development, including developing both specific and general knowledge and skills, exploring career options, and exploring their self-identities beyond sport (Cummins \& O'Boyle, 2015). It follows that holistic talent development and seeking opportunities for multifaceted identity growth is likely beneficial to athletes' wellbeing (Ivarsson et al., 2015). Subsequently, an effective assessment of the scholarship relating to identity development in student-athletes, should consider studies that examine both academic and athletic self-identities to understand how these self-identities co-exist, as well as to explore their correlates.

This review seeks to build upon recent dual career reviews (e.g., Guidotti, Cortis, \& Capranica, 2015; Stambulova \& Wylleman, 2019) by expanding the scope of research beyond a European context and to focus exclusively on the academic and athletic identity development of student-athletes. Specifically, this systematic literature review aims to: (a) identify the available empirical literature simultaneously investigating both academic and athletic identities of student-athletes; (b) identify and interpret relevant themes within this literature; and (c) determine potential directions for future research.

\section{Method}

\section{Search Strategy}

Three databases (PsycINFO, SCOPUS, and SPORTDiscus) that span the disciplines of sports science and psychology, were used to identify published research articles examining both academic and athletic identities of student-athletes. Pre-defined eligibility criteria were applied to the search, namely: peer-reviewed journal articles, English language; full-text availability; and must empirically investigate both academic and athletic identity of tertiary-level, adult student-athletes. Scholarship into dual careers is a relatively recent research trend, therefore all sources were searched 
from January 2000 to May 2019. Records with both quantitative and qualitative (or mixed methods) approaches were included in the search protocol, given that a wide scope of methods were deemed important to explore the nuances of identity development (Brown \& Hartley, 1998). Consistent keyword and title searches were employed using search string synonyms for the three primary study concepts: 'sport', 'student', and 'identity'. Truncation and Booleans were applied to broaden and refine the search. The specific terms that were used were: (sport OR athlet*OR student-athlete) AND (student OR scholar OR education OR school OR university OR academ* OR student-athlete OR dual career), AND (identity). Additionally, the reference lists of recent reviews (Fuller, 2014; Guidotti et al., 2015; Li \& Sum, 2017; Stambulova \& Wylleman, 2019) were assessed, identifying an additional 25 potentially relevant records. The flowchart of the record screening process is outlined in Figure 1 and is consistent with the PRISMA statement for the reporting of information in systematic reviews (Moher, Liberati, Tetzlaff, \& Altman, 2009). After the removal of 33 duplicates, a total of 148 unique records were identified. An initial title and abstract screening was conducted on all 148 records with 39 removed for not fitting the aforementioned inclusion criteria. A full-text review was then conducted on the remaining 109 records, identifying 42 records that were deemed relevant for inclusion in this review.

Of these 42 records, 15 measured both academic and athletic identities directly. The remaining records measured one or both of these identities indirectly, such as

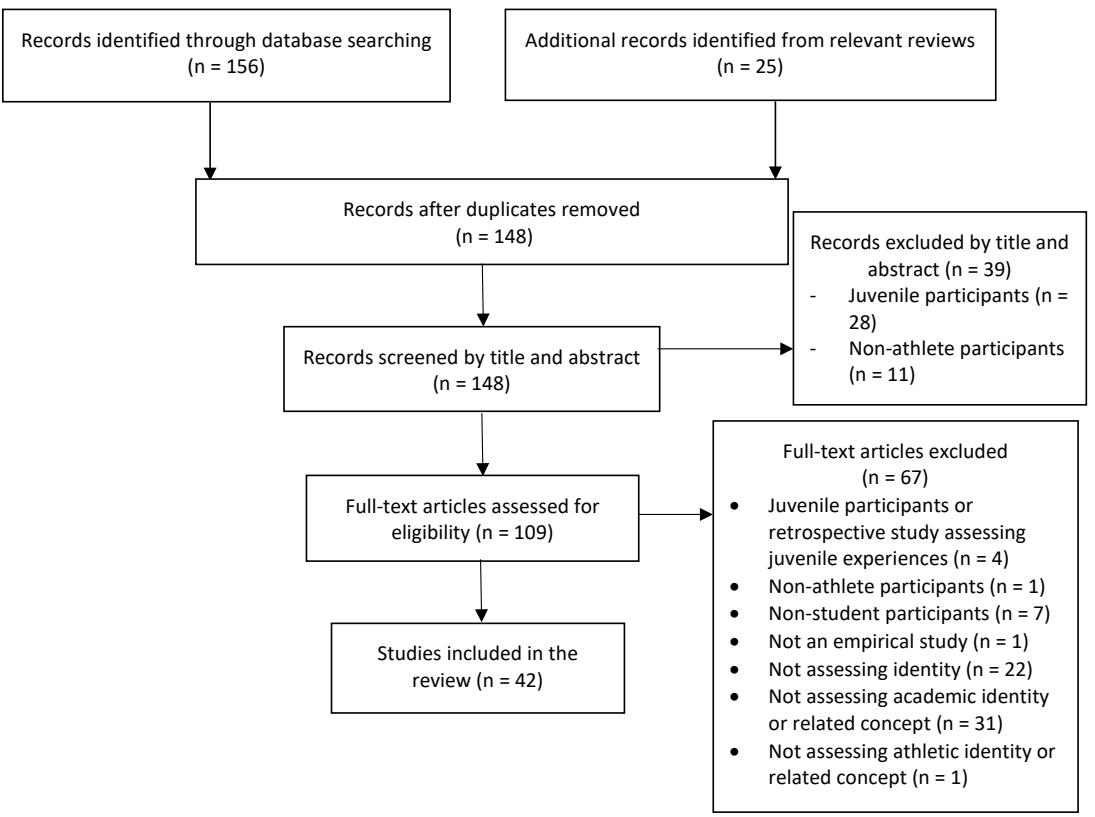

Figure 1. Flowchart of literature screening process (process adapted from Moher et al., 2009). 
measuring indicators of academic experience (Huang, Chou, \& Hung, 2016), academic involvement (Mignano, Brewer, Winter, \& Van Raalte, 2006), or self-perceptions of academic importance (Settles, Sellers, \& Damas, 2002). Given that academic and athletic self-identities are proposed to develop in reference to both intrinsic and extrinsic information, such as comparison of performance relative to others, and to be expressed through educational/performance outcomes and commitment (Skaalvik \& Skaalvik, 2002), records assessing these related concepts were included in this review to holistically capture all relevant research on identity development.

\section{Results and Discussion}

\section{Research Characteristics}

In total, 15 (36\%) studies employed qualitative research methods, 24 (57\%) studies used a quantitative approach, and three (7\%) studies employed a mixed-methods approach. Of the studies with quantitative or mixed methods approaches, nine (33\%) employed the Athletic Identity Measurement Scale (AIMS; Brewer et al., 1993) to assess athletic identity. There was no consistency in how academic identity was measured; two studies (Antshel, VanderDrift, \& Pauline, 2016; Beron \& Piquero, 2016) measured the strength of the academic identity relative to the strength of the athletic identity, such that if one was reported as higher, the other would subsequently be reported as lower. Conversely, although the Academic and Athletic Scale (AAIS; Yukhymenko- Lescroart, 2014; 2018) measured both athletic and academic identities within the one scale, these were treated as discrete subscales, such that a high score on one identity would not necessarily preclude a high score on the other.

Of the 42 records, five $(12 \%)$ were published in the years 2000 to 2004, eight (19\%) from 2005 to 2009, 11 (26\%) from 2010 to 2014, and 18 (43\%) since 2015. Thirty-five $(83 \%)$ records sampled across a variety of sports, three $(7 \%)$ sampled only (or primarily) from American football, two (5\%) from hockey, and the remainder from either football, swimming, or basketball. Two (5\%) studies were conducted in Asia, 13 (31\%) in Europe, one each in Africa (2.5\%) and Australasia (2.5\%), with the remaining $25(59 \%)$ studies conducted in North America. Most of these North American studies (68\%) sampled student-athletes from National Collegiate Athletic Association (NCAA) institutions. Another five of the North American studies $(20 \%)$ sampled from student-athletes competing at non-NCAA intercollegiate levels, with the final three (12\%) studies assessing student-athletes competing across sporting levels. Of the studies conducted outside of North America, most (70\%) sampled across sporting levels (from amateur to international levels), one (6\%) sampled only from semi-professional levels, and four (24\%) sampled only from professional or Olympic levels.

An inductive approach was employed to identify and analyze themes. Key findings were extracted from all studies, after which an iterative process identified higher-order themes for each record (methods adapted from Hatch, 2002). Similar themes were collapsed until the researchers were satisfied that the final themes encapsulated all records. Four over-arching themes were identified: the first theme consists of 
17 studies examining the 'identity development' of student-athletes (see Table 1). The second theme consists of 10 studies examining 'role conflict and wellbeing' of student-athletes (see Table 2). The third theme consists of 16 studies examining 'career maturity and motivation' (see Table 3). The final theme consists of nine studies examining 'student-athlete stereotypes' (see Table 4). Ten studies were identified as examining multiple themes, and therefore were presented across multiple tables.

Table 1

Key Characteristics of Studies Examining Academic and Athletic Identity in Student-Athletes: Theme - Identity Development $(n=17)$

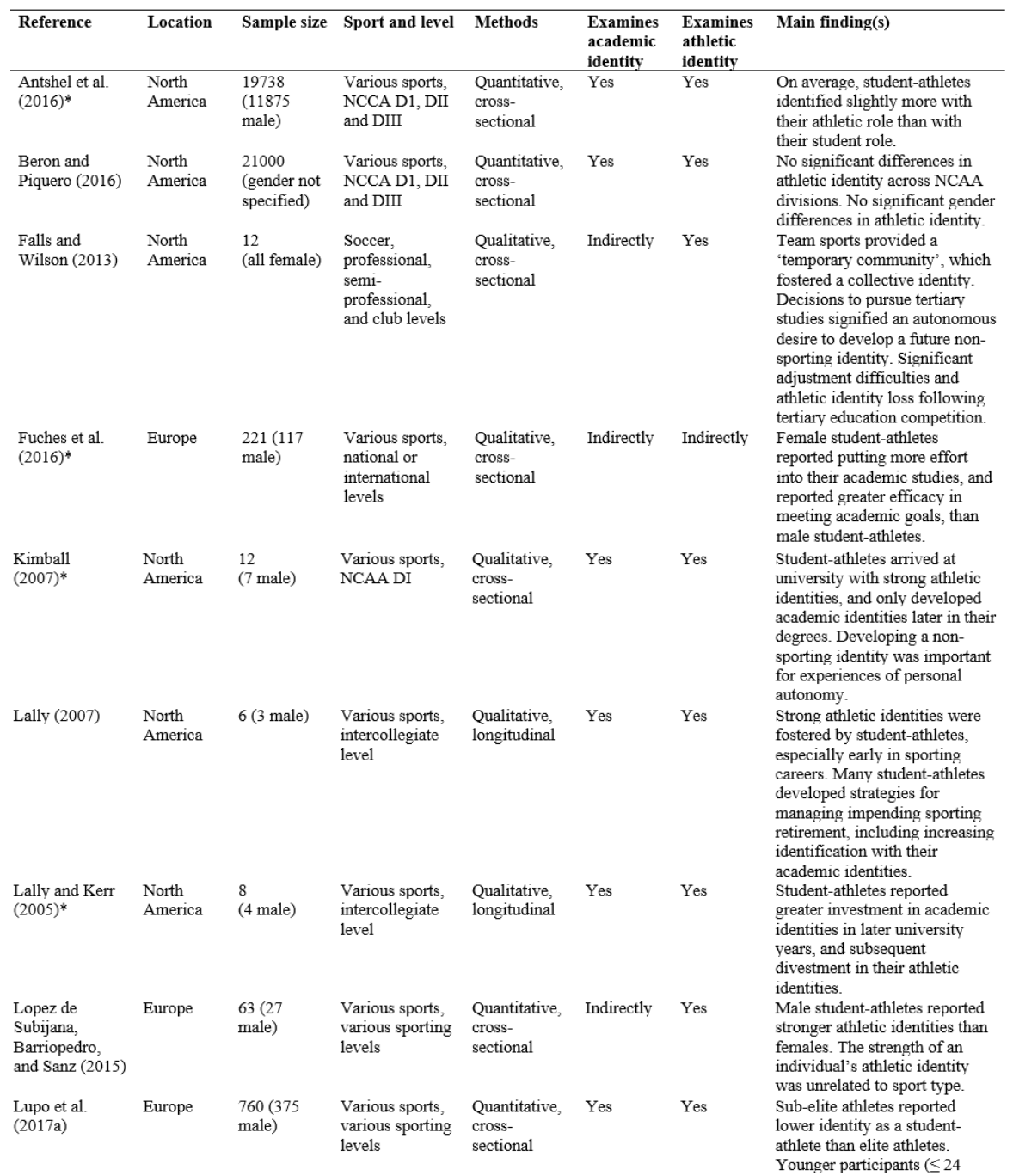




\begin{tabular}{|c|c|c|c|c|c|c|c|}
\hline $\begin{array}{l}\text { Lupo et al. } \\
\text { (2017b)* }\end{array}$ & Europe & $\begin{array}{l}616(306 \\
\text { male) }\end{array}$ & $\begin{array}{l}\text { Various sports, } \\
\text { various sporting } \\
\text { levels }\end{array}$ & $\begin{array}{l}\text { Quantitative, } \\
\text { cross- } \\
\text { sectional }\end{array}$ & Indirectly & Indirectly & $\begin{array}{l}\text { participants. } \\
\text { Validation of the Sports and } \\
\text { Academics Questionnaire } \\
\text { (SAMSAQ) showed female } \\
\text { student-athletes to report } \\
\text { greater academic motivation } \\
\text { compared to males. Sub-elite } \\
\text { athletes reported lower sports } \\
\text { motivation compared to elite } \\
\text { athletes. }\end{array}$ \\
\hline $\begin{array}{l}\text { Lupo et al. } \\
\text { (2012) }\end{array}$ & Europe & $\begin{array}{l}314(118 \\
\text { males) }\end{array}$ & $\begin{array}{l}\text { Various sports, } \\
\text { various sporting } \\
\text { levels }\end{array}$ & $\begin{array}{l}\text { Quantitative, } \\
\text { cross- } \\
\text { sectional }\end{array}$ & Indirectly & Indirectly & $\begin{array}{l}\text { No difference in academic or } \\
\text { sporting motivation between } \\
\text { genders or between types of } \\
\text { sport (team or individual). }\end{array}$ \\
\hline $\begin{array}{l}\text { Miller and Kerr } \\
(2003)^{*}\end{array}$ & $\begin{array}{l}\text { North } \\
\text { America }\end{array}$ & $\begin{array}{l}8 \\
(4 \text { male })\end{array}$ & $\begin{array}{l}\text { Various sports, } \\
\text { intercollegiate } \\
\text { level }\end{array}$ & $\begin{array}{l}\text { Qualitative, } \\
\text { cross- } \\
\text { sectional }\end{array}$ & Yes & Yes & $\begin{array}{l}\text { Student-athletes showed early } \\
\text { over-identification as athletes. } \\
\text { The development of academic } \\
\text { identities was deferred to later } \\
\text { years of university study. }\end{array}$ \\
\hline $\begin{array}{l}\text { Sturm et al. } \\
\text { (2011) }\end{array}$ & $\begin{array}{l}\text { North } \\
\text { America }\end{array}$ & $\begin{array}{l}188 \\
(121 \mathrm{male})\end{array}$ & $\begin{array}{l}\text { Various sports, } \\
\text { NCCA D1 and } \\
\text { DIII }\end{array}$ & $\begin{array}{l}\text { Quantitative, } \\
\text { cross- } \\
\text { sectional }\end{array}$ & Yes & Yes & $\begin{array}{l}\text { Academic identity was stable } \\
\text { throughout university. Females } \\
\text { reported stronger student } \\
\text { identity. No significant } \\
\text { differences between academic } \\
\text { or athletic identities between } \\
\text { NCAA DI and DII student- } \\
\text { athletes }\end{array}$ \\
\hline $\begin{array}{l}\text { Tekavc, et al. } \\
(2015)^{*}\end{array}$ & Europe & $\begin{array}{l}12 \text { ( } 6 \text { male); } \\
\text { all retired } \\
\text { from sports, } \\
6 \text { completed } \\
\text { university }\end{array}$ & $\begin{array}{l}\text { Swimming and } \\
\text { basketball, } \\
\text { professional } \\
\text { level }\end{array}$ & $\begin{array}{l}\text { Qualitative, } \\
\text { cross- } \\
\text { sectional }\end{array}$ & Indirectly & Indirectly & $\begin{array}{l}\text { Female athletes showed more } \\
\text { motivation than males to pursue } \\
\text { academics and to achieve } \\
\text { higher academic grades. } \\
\text { Engagement in academics was } \\
\text { related to personal satisfaction } \\
\text { and self-confidence, } \\
\text { particularly for females. }\end{array}$ \\
\hline $\begin{array}{l}\text { van Rens et al. } \\
\text { (2019) }\end{array}$ & Australasia & $\begin{array}{l}\text { Study 1: } 8 \\
\text { (3 male) } \\
\text { Study 2: } 94 \\
\text { (46 male) }\end{array}$ & $\begin{array}{l}\text { Various sports, } \\
\text { various sporting } \\
\text { levels }\end{array}$ & $\begin{array}{l}\text { Mixed } \\
\text { methods, } \\
\text { cross- } \\
\text { sectional }\end{array}$ & Yes & Yes & $\begin{array}{l}\text { Student-athletes developed both } \\
\text { athletic and academic identities, } \\
\text { although no relationship was } \\
\text { found between the strength of } \\
\text { these two identities. }\end{array}$ \\
\hline $\begin{array}{l}\text { Woodruff and } \\
\text { Schallert } \\
(2008)^{*}\end{array}$ & $\begin{array}{l}\text { North } \\
\text { America }\end{array}$ & $\begin{array}{l}9 \\
(5 \text { male })\end{array}$ & $\begin{array}{l}\text { Various sports, } \\
\text { NCCA D1 }\end{array}$ & $\begin{array}{l}\text { Qualitative, } \\
\text { cross- } \\
\text { sectional }\end{array}$ & Yes & Yes & $\begin{array}{l}\text { Change in domain-specific } \\
\text { motivation was reported to } \\
\text { precede changes to academic or } \\
\text { athletic identity salience. }\end{array}$ \\
\hline $\begin{array}{l}\text { Yukhymenko- } \\
\text { Lescroart } \\
(2014)\end{array}$ & $\begin{array}{l}\text { North } \\
\text { America }\end{array}$ & $\begin{array}{l}596 \\
(307 \text { male) }\end{array}$ & $\begin{array}{l}\text { Various sports, } \\
\text { NCAA DI }\end{array}$ & $\begin{array}{l}\text { Quantitative, } \\
\text { cross- } \\
\text { sectional }\end{array}$ & Yes & Yes & $\begin{array}{l}\text { Student-athletes in club level } \\
\text { sport reported higher academic } \\
\text { identity and lower athletic } \\
\text { identity than those in elite level } \\
\text { sport. Student-athletes reported } \\
\text { stronger athletic identity than } \\
\text { academic identity across } \\
\text { sporting levels. No gender } \\
\text { differences found in the } \\
\text { strength or academic or athletic } \\
\text { identities. }\end{array}$ \\
\hline
\end{tabular}

Note * identifies studies that are presented in more than one table

\section{Identity Development}

A common finding amongst the 17 reviewed papers looking at identity development was that student-athletes simultaneously invested in both their academic and athletic identities (e.g., Kimball, 2007; van Rens et al., 2019; Yukhymenko-Lescroart, 2014). However, student-athletes primarily identified themselves as athletes, with their athletic identity being more central to their self-definition than their academic identity (Antshel et al., 2016; Lally \& Kerr, 2005; Miller \& Kerr, 2003). Students engaging in elite level sport reported stronger identification with the athletic role, compared to those competing at sub-elite levels (Lupo et al., 2017a; 2017b; Yukhymenko-Le- 
scroart, 2014; van Rens et al., 2019). Student-athletes often reported showing an early over-identification with the athletic role (Kimball, 2007; Miller \& Kerr, 2003), which aligns with existing research identifying the high risk of athletic identity foreclosure for elite athletes, particularly in late adolescence (Brewer \& Petitpas, 2017). However, findings suggest that the importance of the athletic identity in student-athletes may weaken over time as alternative roles (e.g., student) are explored (Lally \& Kerr, 2005; Miller \& Kerr, 2002). The weakening of the athletic identity may also be a protective self-regulatory process to minimize the impact of impending loss of an athletic role for those approaching sporting retirement (Lally, 2007). Some student-athletes attempted to proactively manage this impending 'identity crisis' at sporting retirement by further investing in their academic (and other non-sporting) identities (Lally, 2007). Together these results affirm established theory (e.g., Stryker $\&$ Burke, 2000) that identity is both dynamic and multidimensional in structure, and that student-athletes may simultaneously develop and invest in academic and athletic identities based upon their roles in these domains. Results also suggest that for student-athletes, their athletic identity is deeply embedded, and remains central to self-definition until athletic retirement.

Eight of the 17 studies in this theme investigated the role of demographic factors, such as gender, in the identity development process, providing inconsistent results. Female student-athletes reported stronger academic identities (Sturm, Feltz, \& Gilson, 2011), greater motivation towards academics (Lupo et al., 2017b; Tekavc, Wylleman, \& Erpič, 2015), and greater prioritization of academic pursuits (Fuches et al., 2016) compared to their male counterparts. This gender difference was proposed to reflect greater opportunities for an ongoing professional career in sports for men compared with women, hence women may be more motivated to explore non-sporting identities (Fuches et al., 2016; Sturm et al., 2011). However, this finding was not unanimously replicated, with other research failing to show these gender differences (Lupo et al., 2017b; Lupo Tessitore, Capranica, Rauter, \& Doupona-Topic, 2012; Yukhymenko-Lescroart, 2014).

Gender differences have also been observed in relation to the development of athletic identities, with male student-athletes reporting stronger athletic identities compared to females (López de Subijana, Barriopedro, \& Sanz, 2015; Melendez, 2009). Mignano et al. (2006) provided context to these findings, with their work revealing that female student-athletes reported higher levels of athletic identity in same-sex campuses, compared to co-educational campuses. This finding was proposed to reflect an increased salience of the stereotypical 'feminine' role when studying with male students, which may be inconsistent with the athletic stereotype, and may subsequently influence female divestment from their athletic identities. Additionally, direct or indirect feedback from other students (see Ewing \& Allen, 2017; Mortimer et al., 2015), based upon gender stereotypes, may work to legitimate the athlete role identity in males, and weaken the identity in females. Indeed, research beyond the scope of this review has identified a negative relationship between athletic identity and 'femininity' (Lantz \& Schroeder, 1999). Conversely, other research found no gender differences in athletic identity in student-athletes (Beron \& Pique- 
ro, 2016; Yukhymenko-Lescroart, 2014). Inconsistency across these results suggests that gender may influence identity development and related behaviors (Mignano et al., 2006), but that identity development is complex, and that context may play a role in facilitating the influence of gender on identity.

Table 2

Key Characteristics of Studies Examining Academic and Athletic Identity in Student-Athletes: Theme - Role conflict and Wellbeing ( $\mathrm{n}=10)$

\begin{tabular}{|c|c|c|c|c|c|c|c|}
\hline Reference & Location & Sample size & Sport and level & Methods & $\begin{array}{l}\text { Examines } \\
\text { academic } \\
\text { identity }\end{array}$ & $\begin{array}{l}\text { Examines } \\
\text { athletic } \\
\text { identity }\end{array}$ & Main finding(s) \\
\hline $\begin{array}{l}\text { Aquilina } \\
\text { (2013) }\end{array}$ & Europe & 18 (8 male) & $\begin{array}{l}\text { Various sports, } \\
\text { Olympic or } \\
\text { professional } \\
\text { levels }\end{array}$ & $\begin{array}{l}\text { Qualitative, } \\
\text { cross- } \\
\text { sectional }\end{array}$ & Indirectly & Indirectly & $\begin{array}{l}\text { Balance between dual roles is } \\
\text { required to successfully meet the } \\
\text { demands of education and sport. } \\
\text { Older student-athletes were more } \\
\text { successful in achieving balance. }\end{array}$ \\
\hline $\begin{array}{l}\text { Brown et al. } \\
(2015)\end{array}$ & Europe & $\begin{array}{l}9 \text { ( } 5 \text { male); } 6 \\
\text { current } \\
\text { student- } \\
\text { athletes, } 3 \\
\text { recently } \\
\text { graduated }\end{array}$ & $\begin{array}{l}\text { Various sports, } \\
\text { various sporting } \\
\text { levels }\end{array}$ & $\begin{array}{l}\text { Qualitative, } \\
\text { cross- } \\
\text { sectional }\end{array}$ & Yes & Yes & $\begin{array}{l}\text { Students reported struggling to } \\
\text { meet the demands of sport and } \\
\text { academics. Academic flexibility } \\
\text { assisted students in meeting } \\
\text { academic goals, such as allowing } \\
\text { students to change between lab } \\
\text { groups to attend competition. }\end{array}$ \\
\hline $\begin{array}{l}\text { Fuches et al. } \\
(2016)^{*}\end{array}$ & Europe & $\begin{array}{l}221(117 \\
\text { male) }\end{array}$ & $\begin{array}{l}\text { Various sports, } \\
\text { national or } \\
\text { international } \\
\text { levels }\end{array}$ & $\begin{array}{l}\text { Qualitative, } \\
\text { cross- } \\
\text { sectional }\end{array}$ & Indirectly & Indirectly & $\begin{array}{l}\text { Perceived role conflict was greater } \\
\text { for student-athletes competing at an } \\
\text { international level compared to } \\
\text { national level. Social support was } \\
\text { helpful in supporting student- } \\
\text { athletes to balance dual careers. }\end{array}$ \\
\hline $\begin{array}{l}\text { Geraniosova } \\
\text { and } \\
\text { Ronkainen } \\
(2014)^{*}\end{array}$ & Europe & 5 (2 male) & $\begin{array}{l}\text { Various sports, } \\
\text { amateur and } \\
\text { professional } \\
\text { levels }\end{array}$ & $\begin{array}{l}\text { Qualitative, } \\
\text { cross- } \\
\text { sectional }\end{array}$ & Indirectly & Indirectly & $\begin{array}{l}\text { Family was identified as a key } \\
\text { emotional and financial support. } \\
\text { Student-athletes perceived limited } \\
\text { structured support was available to } \\
\text { help them balance multiple role } \\
\text { demands. }\end{array}$ \\
\hline $\begin{array}{l}\text { Healy et al. } \\
(2016)\end{array}$ & Europe & $\begin{array}{l}204(103 \\
\text { male) }\end{array}$ & $\begin{array}{l}\text { Various sports, } \\
\text { various sporting } \\
\text { levels }\end{array}$ & $\begin{array}{l}\text { Quantitative, } \\
\text { cross- } \\
\text { sectional }\end{array}$ & Indirectly & Indirectly & $\begin{array}{l}\text { Student-athletes reported moderate } \\
\text { levels of interference between sport } \\
\text { and academic goals. Some student- } \\
\text { athletes reported motivational } \\
\text { facilitation between sport and } \\
\text { academic goals. }\end{array}$ \\
\hline $\begin{array}{l}\text { Killeya-Jones } \\
(2005)\end{array}$ & $\begin{array}{l}\text { North } \\
\text { America }\end{array}$ & $\begin{array}{l}40 \\
\text { (all male) }\end{array}$ & $\begin{array}{l}\text { NFL, } \\
\text { NCCA D1 }\end{array}$ & $\begin{array}{l}\text { Quantitative, } \\
\text { cross- } \\
\text { sectional }\end{array}$ & Yes & Yes & $\begin{array}{l}\text { Life satisfaction, academic } \\
\text { satisfaction, and wellbeing of } \\
\text { student-athletes was lower when } \\
\text { there was a greater discrepancy in } \\
\text { attributes between the academic } \\
\text { identity and athletic identity. }\end{array}$ \\
\hline $\begin{array}{l}\text { Lupo et al. } \\
(2015)^{*}\end{array}$ & Europe & $\begin{array}{l}524(287 \\
\text { male) }\end{array}$ & $\begin{array}{l}\text { Various sports, } \\
\text { international } \\
\text { and national } \\
\text { levels }\end{array}$ & $\begin{array}{l}\text { Quantitative, } \\
\text { cross- } \\
\text { sectional }\end{array}$ & Indirectly & Indirectly & $\begin{array}{l}\text { National Federations were effective } \\
\text { in negotiating for academic } \\
\text { flexibility with education } \\
\text { institutions, including altered exam } \\
\text { schedules and tutoring. }\end{array}$ \\
\hline $\begin{array}{l}\text { Miller and } \\
\text { Kerr }(2003)^{*}\end{array}$ & $\begin{array}{l}\text { North } \\
\text { America }\end{array}$ & $\begin{array}{l}8 \\
(4 \text { male })\end{array}$ & $\begin{array}{l}\text { Various sports, } \\
\text { intercollegiate } \\
\text { level }\end{array}$ & $\begin{array}{l}\text { Qualitative, } \\
\text { cross- } \\
\text { sectional }\end{array}$ & Yes & Yes & $\begin{array}{l}\text { Academic and athletic roles } \\
\text { compete. Student-athletes reduced } \\
\text { social interaction as a method to } \\
\text { reduce work-life conflict and to } \\
\text { rectify poor performance in } \\
\text { academics. }\end{array}$ \\
\hline $\begin{array}{l}\text { Settles et al. } \\
(2002)\end{array}$ & $\begin{array}{l}\text { North } \\
\text { America }\end{array}$ & $\begin{array}{l}200 \\
(87 \text { male })\end{array}$ & $\begin{array}{l}\text { Various sports, } \\
\text { NCCA D1 }\end{array}$ & $\begin{array}{l}\text { Quantitative, } \\
\text { cross- } \\
\text { sectional }\end{array}$ & Indirectly & Yes & $\begin{array}{l}\text { A negative association was found } \\
\text { between role conflict and wellbeing } \\
\text { in student-athletes. } \\
\text { Compartmentalization of study and } \\
\text { sport roles had wellbeing benefits } \\
\text { in student-athletes. }\end{array}$ \\
\hline $\begin{array}{l}\text { Woodruff and } \\
\text { Schallert } \\
(2008)^{*}\end{array}$ & $\begin{array}{l}\text { North } \\
\text { America }\end{array}$ & $\begin{array}{l}9 \\
(5 \text { male })\end{array}$ & $\begin{array}{l}\text { Various sports, } \\
\text { NCCA D1 }\end{array}$ & $\begin{array}{l}\text { Qualitative, } \\
\text { cross- } \\
\text { sectional }\end{array}$ & Yes & Yes & $\begin{array}{l}\text { Sporting and academic roles may } \\
\text { represent conflicting motivations. }\end{array}$ \\
\hline
\end{tabular}




\section{Identity, Role Conflict, and Wellbeing}

Ten studies in this review investigated role conflict between academic and athletic identities. Role conflict may occur when the demands of one role or identity, such as sport, interfere with meeting demands of another role or identity, such as academics (van Rens, Borkoles, Farrow, Curran, \& Polman, 2016). Qualitative work (e.g., Healy, Ntoumanis, \& Duda, 2016; Miller \& Kerr, 2003) suggests that academic roles and student roles necessarily exist in competition, and that simultaneous commitment to both roles and subsequent identities may be difficult to maintain. Role conflict has been cited as a source of psychological stress in student-athletes and is related to poorer wellbeing and life satisfaction (Killeya-Jones, 2005; Settles et al., 2002).

Findings indicate that many student-athletes have developed strategies to mitigate conflict between their academic and athletic roles, such as enhancing role convergence, role compartmentalization, time prioritization and management, expectation reassessment, and leveraging personal resources, such as social and family support (Brown et al., 2015; Geraniosova \& Ronkainen, 2014; Killeya-Jones 2005; Settles et al., 2002). Successful implementation of these strategies was deemed beneficial to one's wellbeing, with achieving a balance between academics and athletics becoming easier to obtain with greater life experience and age (Aquilina, 2013). However, conflicting results suggest that student-athletes were not always successful in balancing multiple role demands, with time management cited as a major barrier to successfully engaging in dual careers, often resulting in avoidance-related coping strategies, such as disengagement from study or failure to attend mandatory classes (Brown et al., 2015).

Conscious shifting of the centrality of domain-specific identities, across time, may also be an important strategy in reducing role conflict, supporting wellbeing, and to achieve goals in both sporting and academic domains (Settles et al., 2002). For instance, during athletic competition, the athletic identity is likely to be highly central to the individual's sense of self; whereas during university exams the academic identity becomes more central. Indeed, one study reported that student-athletes can rapidly shift the salience of their academic and athletic identities within the span of one experimental session, as they complete different types of tasks (Yopyk \& Prentice, 2005). This self-regulatory process may facilitate responsiveness to changing role and performance demands and performance optimization (Yopyk \& Prentice, 2005). These findings align with existing relational identity theories (e.g., Burke \& Stets, 2009) conceptualizing role identities as fluid in structure, wherein the salience of domain-specific identities may shift over time in response to role and task demands (Ashforth, Harrison, \& Corley, 2008).

\section{Identity, Career Maturity, and Motivation}

The development of a strong athletic identity and an over-commitment to the athletic role may reduce a student's propensity to explore non-sporting vocations, which may have implications for their post-sporting career development (Huang et al., 2016). Indeed, athletic identity was found to negatively relate to academic adjustment (Me- 
Table 3

Key Characteristics of Studies Examining Both Academic and Athletic Identity in Student-Athletes: Theme - Identity, Career Maturity and Motivation $(n=16)$

\begin{tabular}{|c|c|c|c|c|c|c|c|}
\hline Reference & Location & Sample size & Sport and level & Methods & $\begin{array}{l}\text { Examines } \\
\text { academic } \\
\text { identity }\end{array}$ & $\begin{array}{l}\text { Examines } \\
\text { athletic } \\
\text { identity }\end{array}$ & Main finding(s) \\
\hline $\begin{array}{l}\text { Antshel et al. } \\
(2016)^{*}\end{array}$ & $\begin{array}{l}\text { North } \\
\text { America }\end{array}$ & $\begin{array}{l}19738 \\
(60 \% \text { male })\end{array}$ & $\begin{array}{l}\text { Various sports, } \\
\text { NCCA D1, DII } \\
\text { and DIII }\end{array}$ & $\begin{array}{l}\text { Quantitative, } \\
\text { cross- } \\
\text { sectional }\end{array}$ & Yes & Yes & $\begin{array}{l}\text { In academically struggling } \\
\text { student-athletes, GPA predicted } \\
\text { use of academic support services } \\
\text { only when academic identity was } \\
\text { prominent }\end{array}$ \\
\hline $\begin{array}{l}\text { Erpiē et al. } \\
(2004)\end{array}$ & Europe & $\begin{array}{l}85 \text { ( } 54 \text { male); } \\
\text { all retired from } \\
\text { sports, } 67.1 \% \\
\text { completed } \\
\text { university }\end{array}$ & $\begin{array}{l}\text { Various sports, } \\
\text { various sporting } \\
\text { levels }\end{array}$ & $\begin{array}{l}\text { Quantitative, } \\
\text { cross- } \\
\text { sectional }\end{array}$ & Indirectly & Yes & $\begin{array}{l}\text { Most participants reported } \\
\text { successfully adapting to their } \\
\text { post-sporting lives after athletic } \\
\text { retirement. A stronger athletic } \\
\text { identity was related to more } \\
\text { psychological difficulties after } \\
\text { sports. Higher educated } \\
\text { participants reported fewer } \\
\text { occupation difficulties (finding } \\
\text { work, financial difficulties) }\end{array}$ \\
\hline $\begin{array}{l}\text { Foster and } \\
\text { Huml (2017) }\end{array}$ & $\begin{array}{l}\text { North } \\
\text { America }\end{array}$ & 546 (385 male) & $\begin{array}{l}\text { Various sports, } \\
\text { NCCA D1, DII } \\
\text { and DIII }\end{array}$ & $\begin{array}{l}\text { Quantitative, } \\
\text { cross- } \\
\text { sectional }\end{array}$ & Indirectly & Yes & $\begin{array}{l}\text { Student-athletes with stronger } \\
\text { athletic identities were more } \\
\text { likely to choose a degree with } \\
\text { less academic rigor }\end{array}$ \\
\hline $\begin{array}{l}\text { Harrison and } \\
\text { Lawrence } \\
(2004)\end{array}$ & $\begin{array}{l}\text { North } \\
\text { America }\end{array}$ & 143 (79 male) & $\begin{array}{l}\text { Various sports, } \\
\text { NCCA DII }\end{array}$ & $\begin{array}{l}\text { Mixed } \\
\text { methods, } \\
\text { cross- } \\
\text { sectional }\end{array}$ & Indirectly & Indirectly & $\begin{array}{l}\text { A future career focus was } \\
\text { reported to facilitate successful } \\
\text { transitions out of sport for } \\
\text { student-athletes. Student-athletes } \\
\text { perceived that they were active } \\
\text { agents in shaping their future } \\
\text { career paths. }\end{array}$ \\
\hline $\begin{array}{l}\text { Huang et al. } \\
(2016)\end{array}$ & Asia & $\begin{array}{l}345 \\
(224 \text { male) }\end{array}$ & $\begin{array}{l}\text { Various sports, } \\
\text { semi- } \\
\text { professional } \\
\text { levels }\end{array}$ & $\begin{array}{l}\text { Quantitative, } \\
\text { cross- } \\
\text { sectional }\end{array}$ & Indirectly & Yes & $\begin{array}{l}\text { The negative relationship } \\
\text { between enriched university } \\
\text { experiences and career barriers } \\
\text { was mediated by career self- } \\
\text { efficacy. Student-athletes with } \\
\text { higher levels of athletic identity } \\
\text { were less likely to use university } \\
\text { learning resources. }\end{array}$ \\
\hline $\begin{array}{l}\text { Kimball } \\
(2007)^{*}\end{array}$ & $\begin{array}{l}\text { North } \\
\text { America }\end{array}$ & $\begin{array}{l}12 \\
(7 \text { male })\end{array}$ & $\begin{array}{l}\text { Various sports, } \\
\text { NCAA DI }\end{array}$ & $\begin{array}{l}\text { Qualitative, } \\
\text { cross- } \\
\text { sectional }\end{array}$ & Yes & Yes & $\begin{array}{l}\text { NCAA students-athletes were } \\
\text { required to nominate their major } \\
\text { early in their degrees, which } \\
\text { meant that many did not have } \\
\text { time to organically develop their } \\
\text { interests. This resulted in many } \\
\text { participants enrolled in courses } \\
\text { that did not intrinsically interest } \\
\text { them. Participants reported that } \\
\text { developing non-sporting } \\
\text { identities was important } \\
\text { preparation for life after sport. }\end{array}$ \\
\hline $\begin{array}{l}\text { Lally and Kerr } \\
(2005)^{*}\end{array}$ & $\begin{array}{l}\text { North } \\
\text { America }\end{array}$ & $\begin{array}{l}8 \\
(4 \text { male })\end{array}$ & $\begin{array}{l}\text { Various sports, } \\
\text { intercollegiate } \\
\text { level }\end{array}$ & $\begin{array}{l}\text { Qualitative, } \\
\text { longitudinal }\end{array}$ & Yes & Yes & $\begin{array}{l}\text { Non-sporting career plans were } \\
\text { ill-defined when entering } \\
\text { university but developed over } \\
\text { time. By the final year of } \\
\text { university, many student-athletes } \\
\text { no longer viewed sport as a } \\
\text { viable future career option. }\end{array}$ \\
\hline $\begin{array}{l}\text { Lupo et al. } \\
(2015)^{*}\end{array}$ & Europe & 524 (287 male) & $\begin{array}{l}\text { Various sports, } \\
\text { International } \\
\text { and national }\end{array}$ & $\begin{array}{l}\text { Quantitative, } \\
\text { cross- } \\
\text { sectional }\end{array}$ & Indirectly & Indirectly & $\begin{array}{l}\text { Student-athletes expected a } \\
\text { smoother transition out of sports } \\
\text { when their State offered dual- }\end{array}$ \\
\hline
\end{tabular}




\begin{tabular}{|c|c|c|c|c|c|c|c|}
\hline \multicolumn{7}{|c|}{ levels } & \multirow{2}{*}{$\begin{array}{l}\text { career policies. Athletic } \\
\text { achievement may facilitate post- } \\
\text { university work in sport-related } \\
\text { careers (e.g., as coaches, } \\
\text { trainers). } \\
\text { Validation of the Sports and } \\
\text { Academics Questionnaire } \\
\text { (SAMSAQ) showed sub-elite } \\
\text { athletes reported lower career } \\
\text { motivation than elite athletes. }\end{array}$} \\
\hline $\begin{array}{l}\text { Lupo et al. } \\
(2017 \mathrm{~b})^{*}\end{array}$ & Europe & 616 (306 male) & $\begin{array}{l}\text { Various sports, } \\
\text { various sporting } \\
\text { levels }\end{array}$ & $\begin{array}{l}\text { Quantitative, } \\
\text { cross- } \\
\text { sectional }\end{array}$ & Indirectly & Indirectly & \\
\hline $\begin{array}{l}\text { Melendez } \\
\text { (2009) }\end{array}$ & $\begin{array}{l}\text { North } \\
\text { America }\end{array}$ & $\begin{array}{l}101 \\
\text { (63 male) }\end{array}$ & $\begin{array}{l}\text { Various sports, } \\
\text { NCCA D1 }\end{array}$ & $\begin{array}{l}\text { Quantitative, } \\
\text { cross- } \\
\text { sectional }\end{array}$ & Indirectly & Yes & $\begin{array}{l}\text { A strong athletic identity was } \\
\text { associated with lower academic } \\
\text { adjustment and personal- } \\
\text { emotional adjustment in student- } \\
\text { athletes }\end{array}$ \\
\hline $\begin{array}{l}\text { Stoltenburg et } \\
\text { al. (2011) }\end{array}$ & $\begin{array}{l}\text { North } \\
\text { America }\end{array}$ & $\begin{array}{l}7(5 \text { males }) \text {; } \\
\text { former athletes } \\
\text { who had } \\
\text { experienced } \\
\text { career ending } \\
\text { injury }\end{array}$ & $\begin{array}{l}\text { Various sports, } \\
\text { NCCA D1 and } \\
\text { DII }\end{array}$ & $\begin{array}{l}\text { Qualitative, } \\
\text { cross- } \\
\text { sectional }\end{array}$ & Indirectly & Yes & $\begin{array}{l}\text { Students were able to prioritize } \\
\text { academics after career ending } \\
\text { sport injuries. Holding a strong } \\
\text { athletic identity made the } \\
\text { transition out of sports more } \\
\text { difficult. }\end{array}$ \\
\hline $\begin{array}{l}\text { Sum et al. } \\
\text { (2017) }\end{array}$ & Asia & 8 (4 males) & $\begin{array}{l}\text { Various sports, } \\
\text { various sporting } \\
\text { levels }\end{array}$ & $\begin{array}{l}\text { Qualitative, } \\
\text { cross- } \\
\text { sectional }\end{array}$ & Indirectly & Indirectly & $\begin{array}{l}\text { The influence of parents and } \\
\text { coaches on the career } \\
\text { development of student-athletes } \\
\text { reduced as they progressed } \\
\text { through university. }\end{array}$ \\
\hline $\begin{array}{l}\text { Tekavc, et al. } \\
(2015)^{*}\end{array}$ & Europe & $\begin{array}{l}12(6 \text { male); } \\
\text { all retired from } \\
\text { sports, } 6 \\
\text { completed } \\
\text { university }\end{array}$ & $\begin{array}{l}\text { Swimming and } \\
\text { basketball, elite } \\
\text { level }\end{array}$ & $\begin{array}{l}\text { Qualitative, } \\
\text { cross- } \\
\text { sectional }\end{array}$ & Indirectly & Yes & $\begin{array}{l}\text { Female athletes reported } \\
\text { investing more time into } \\
\text { considering their future career } \\
\text { paths, than males. Females were } \\
\text { also more likely than their male } \\
\text { counterparts to choose a post- } \\
\text { sporting career path outside of } \\
\text { sports }\end{array}$ \\
\hline $\begin{array}{l}\text { Torregrosa et } \\
\text { al. (2015) }\end{array}$ & Europe & $\begin{array}{l}15(10 \mathrm{men}) \\
\text { all retired from } \\
\text { sports }\end{array}$ & $\begin{array}{l}\text { Various sports, } \\
\text { Olympic level }\end{array}$ & $\begin{array}{l}\text { Qualitative, } \\
\text { longitudinal }\end{array}$ & Yes & Yes & $\begin{array}{l}\text { A unidimensional self-identity } \\
\text { focused on sport was related to } \\
\text { poorer career planning and } \\
\text { transitions. Some student- } \\
\text { athletes reported studying } \\
\text { degrees related to sports (e.g., } \\
\text { sports science) to facilitate future } \\
\text { sport-related employment and } \\
\text { career transition }\end{array}$ \\
\hline $\begin{array}{l}\text { Tshube and } \\
\text { Feltz (2015) }\end{array}$ & Africa & $\begin{array}{l}17 \text { (12 males); } \\
\text { all retired from } \\
\text { sports, } 10 \\
\text { participated in } \\
\text { university }\end{array}$ & $\begin{array}{l}\text { Various sports, } \\
\text { Olympic or } \\
\text { international } \\
\text { levels }\end{array}$ & $\begin{array}{l}\text { Mixed } \\
\text { methods, } \\
\text { cross- } \\
\text { sectional }\end{array}$ & Indirectly & Indirectly & $\begin{array}{l}\text { Athletes use education to prepare } \\
\text { for sporting retirement and a } \\
\text { post-sporting career. An } \\
\text { exclusive focus on sports was } \\
\text { related to a more difficult } \\
\text { transition out of sports. }\end{array}$ \\
\hline $\begin{array}{l}\text { Yukhymenko- } \\
\text { Lescroart } \\
\text { (2018) }\end{array}$ & $\begin{array}{l}\text { North } \\
\text { America }\end{array}$ & $\begin{array}{l}1151 \\
(55.8 \% \text { male })\end{array}$ & $\begin{array}{l}\text { Various sports, } \\
\text { NCCA D1 }\end{array}$ & $\begin{array}{l}\text { Quantitative, } \\
\text { cross- } \\
\text { sectional }\end{array}$ & Yes & Yes & $\begin{array}{l}\text { Athletic identity negatively } \\
\text { predicted ethical sporting } \\
\text { conduct, academic mastery and } \\
\text { academic performance goals. } \\
\text { Academic identity positively } \\
\text { predicted ethical sporting } \\
\text { conduct, academic mastery, and } \\
\text { academic performance goals. }\end{array}$ \\
\hline
\end{tabular}

lendez, 2009), academic mastery goals, and academic performance goals (Yukhymenko-Lescroart, 2018), and the success of post-sporting career transitions (Erpič, Wylleman, \& Zupančič, 2004; Stoltenburg, Kamphoff, \& Bremer, 2011; Torregrosa, Ramis, Pallarés, Azócar, \& Selva, 2015; Tshube \& Feltz, 2015). Student-athletes reporting a strong athletic identity were also less likely to utilize academic learning resources and support services (Antshel et al., 2016; Huang et al., 2016), and were more likely to choose an 'easier' degree, thus may have prioritized short-term sporting goals over longer-term career goals (Foster \& Huml, 2017).

Compared to athletic identity, the development of an academic identity was found to relate to positive career outcomes and career readiness (Lally \& Kerr, 2005). 
A longitudinal study reported that student-athletes often had ill-defined non-sporting career plans when starting university, but as they reached the later years of their education they began to invest more in non-sporting identities and in their academic roles and develop more tangible and autonomous career plans (Lally \& Kerr, 2005; Sum et al., 2017). Indeed, approaching graduation, many student-athletes reported no longer perceiving athletics as a viable future career plan (Lally \& Kerr, 2005). Alternatively, many student-athletes reported seeking future employment in sports-related industries and some subsequently sought out relevant degrees (e.g., sports science) to facilitate employment in these roles (Torregrosa et al., 2015). This divestment in sport and focus on developing a broader skill base aligns with Heckhausen's life span model of aging (Schulz \& Heckhausen, 1996), highlighting that re-training and skill diversification may be required for athletes who have overinvested in highly specialized elite sports. In this vein, engaging in education acts as a compensatory behavior to foster the development of new broader academic and professional skills required to attain future non-sporting vocational goals. Given these findings, and that studies beyond the scope of this review (e.g., Anderson, 2012; Stambulova, Stephan, \& Japhag, 2007) have identified career planning as related to emotional wellbeing and coping during sporting retirement, the development of a strong academic identity is proposed to be important in facilitating successful career transitions and the development of post-sporting careers across genders.

\section{Identity and Student-Athlete Stereotypes}

In total, nine studies examined stereotypes related to student-athletes, with eight of those studies conducted in North America. These stereotypes were primarily based in perceptions that student-athletes were attending university solely on sporting merit, citing the 'dumb jock' stereotype (e.g., Bimper, 2014; Stone, Harrison, \& Mottley, 2012; Yopyk \& Prentice, 2005). African-American student-athletes were found to be most vulnerable to negative stereotype threat (Bimper, 2014; Stone et al., 2012), and research beyond this review (e.g., Cooper, 2012) has suggested that this may be particularly pervasive in predominately white institutions. Researchers have conjectured that compared to African-American student-athletes, white student-athletes may explicitly and/or implicitly receive greater on-campus support, which fosters positive associations with the academic role and buffers them from stereotype threat (Stone et al., 2012). One further study, conducted in Europe, found that negative stereotypes of students-athletes pervaded beyond North America, with student-athletes perceiving that university staff had lower academic expectations of them, compared to non-athlete students (Geraniosova \& Ronkainen, 2014). In investigating the pervasiveness of student-athlete stereotypes, three studies consistently reported that artificially priming the athletic identity, by presenting samples of student-athletes with a test paper titled 'student-athlete' or asking them to write about a recent athletic event, caused a decline in academic task performance (Riciputi \& Erdal, 2017; Stone et al., 2012; Yopyk \& Prentice, 2005), and in academic self-regard (Yopyk \& Prentice, 2005). These findings affirm concerns that that student-athletes are vulnerable to negative stereotyping (Simon, Bosworth, Fujita, \& Jensen, 2007). Student-athletes 
Table 4

Key Characteristics of Studies Examining Academic identity and Athletic Identity in Student-Athletes: Theme - Student-athlete Stereotypes (n = 9)

\begin{tabular}{|c|c|c|c|c|c|c|c|}
\hline Reference & Location & Sample size & Sport and level & Methods & $\begin{array}{l}\text { Examines } \\
\text { academic } \\
\text { identity }\end{array}$ & $\begin{array}{l}\text { Examines } \\
\text { athletic } \\
\text { identity }\end{array}$ & Main finding(s) \\
\hline $\begin{array}{l}\text { Bimper } \\
(2014)\end{array}$ & $\begin{array}{l}\text { North } \\
\text { America }\end{array}$ & $\begin{array}{l}255 \\
\text { (all male) }\end{array}$ & NFL, NCCA DI & $\begin{array}{l}\text { Quantitative, } \\
\text { cross-sectional }\end{array}$ & Indirectly & Yes & $\begin{array}{l}\text { Athletic identity negatively } \\
\text { predicted academic outcomes in } \\
\text { African American student- } \\
\text { athletes. No link was found } \\
\text { between racial identity and } \\
\text { academic outcomes. }\end{array}$ \\
\hline $\begin{array}{l}\text { Blodgett and } \\
\text { Schinke } \\
(2015)\end{array}$ & $\begin{array}{l}\text { North } \\
\text { America }\end{array}$ & $\begin{array}{l}13 \text { ( } 8 \text { male), } \\
4 \text { at } \\
\text { university }\end{array}$ & $\begin{array}{l}\text { Hockey, various } \\
\text { sporting levels }\end{array}$ & $\begin{array}{l}\text { Qualitative, } \\
\text { cross-sectional }\end{array}$ & Indirectly & Yes & $\begin{array}{l}\text { Native Canadian student- } \\
\text { athletes experienced backlash } \\
\text { from their own communities for } \\
\text { pursuing Euro-Canadian career } \\
\text { pathways. Pursuing a dual } \\
\text { career may be a way for } \\
\text { minority groups to reduce } \\
\text { cultural stereotyping }\end{array}$ \\
\hline $\begin{array}{l}\text { Feltz et al. } \\
(2013)\end{array}$ & $\begin{array}{l}\text { North } \\
\text { America }\end{array}$ & $\begin{array}{l}318 \\
\text { (111 male) }\end{array}$ & $\begin{array}{l}\text { Various sports, } \\
\text { NCCA DI, DII } \\
\text { and DIII }\end{array}$ & $\begin{array}{l}\text { Quantitative, } \\
\text { cross-sectional }\end{array}$ & Indirectly & Yes & $\begin{array}{l}\text { Athletic identity positively } \\
\text { predicted susceptibility to } \\
\text { stereotype threat. Athletic } \\
\text { identity tended to be higher in } \\
\text { student-athletes when they } \\
\text { perceived their coaches had } \\
\text { lower belief in their academic } \\
\text { ability }\end{array}$ \\
\hline $\begin{array}{l}\text { Geraniosova } \\
\text { and } \\
\text { Ronkainen } \\
(2014)^{*}\end{array}$ & Europe & 5 (2 male) & $\begin{array}{l}\text { Various sports, } \\
\text { amateur and } \\
\text { professional } \\
\text { levels }\end{array}$ & $\begin{array}{l}\text { Qualitative, } \\
\text { cross-sectional }\end{array}$ & Indirectly & Indirectly & $\begin{array}{l}\text { Student-athletes perceived that } \\
\text { university staff perceived them } \\
\text { as less academically able, } \\
\text { compared with non-athlete } \\
\text { students. }\end{array}$ \\
\hline $\begin{array}{l}\text { Hawley et al. } \\
\text { (2014) }\end{array}$ & $\begin{array}{l}\text { North } \\
\text { America }\end{array}$ & $\begin{array}{l}245 \\
(150 \text { male); } \\
71 \text { student- } \\
\text { athletes and } \\
174 \text { non } \\
\text { student- } \\
\text { athletes }\end{array}$ & $\begin{array}{l}\text { Primarily NFL, } \\
\text { intercollegiate } \\
\text { level }\end{array}$ & $\begin{array}{l}\text { Quantitative, } \\
\text { experimental, } \\
\text { cross-sectional }\end{array}$ & Indirectly & Indirectly & $\begin{array}{l}\text { Student-athletes were judged } \\
\text { more harshly by other students } \\
\text { for deviant behaviors. }\end{array}$ \\
\hline $\begin{array}{l}\text { Mignano et } \\
\text { al. }(2006)\end{array}$ & $\begin{array}{l}\text { North } \\
\text { America }\end{array}$ & $\begin{array}{l}145 \\
\text { (all female) }\end{array}$ & $\begin{array}{l}\text { Various sports, } \\
\text { NCAA DIII }\end{array}$ & $\begin{array}{l}\text { Quantitative, } \\
\text { cross-sectional }\end{array}$ & Indirectly & Yes & $\begin{array}{l}\text { Athletic identity and student } \\
\text { involvement were higher in } \\
\text { females attending same-sex } \\
\text { universities compared to those } \\
\text { at coeducational universities }\end{array}$ \\
\hline $\begin{array}{l}\text { Riciputi and } \\
\text { Erdal (2017) }\end{array}$ & $\begin{array}{l}\text { North } \\
\text { America }\end{array}$ & $\begin{array}{l}60 \\
(33 \text { male })\end{array}$ & $\begin{array}{l}\text { Various sports, } \\
\text { NCAA DIII }\end{array}$ & $\begin{array}{l}\text { Quantitative, } \\
\text { experimental, } \\
\text { cross-sectional }\end{array}$ & Indirectly & Indirectly & $\begin{array}{l}\text { Priming with the athletic } \\
\text { stereotype resulted in a decrease } \\
\text { in effort and performance in a } \\
\text { mathematics assessment. No } \\
\text { effect of gender }\end{array}$ \\
\hline $\begin{array}{l}\text { Stone et al. } \\
(2012)\end{array}$ & $\begin{array}{l}\text { North } \\
\text { America }\end{array}$ & $\begin{array}{l}151 \\
\text { (gender not } \\
\text { listed) }\end{array}$ & $\begin{array}{l}\text { Various sports, } \\
\text { various sporting } \\
\text { levels }\end{array}$ & $\begin{array}{l}\text { Quantitative, } \\
\text { experimental, } \\
\text { cross-sectional }\end{array}$ & Indirectly & Indirectly & $\begin{array}{l}\text { Priming with the 'scholar- } \\
\text { athlete' identity related to } \\
\text { poorer verbal reasoning test } \\
\text { results. African American } \\
\text { student-athletes were more } \\
\text { susceptible to negative } \\
\text { stereotyping }\end{array}$ \\
\hline $\begin{array}{l}\text { Yopyk and } \\
\text { Prentice } \\
(2005)\end{array}$ & $\begin{array}{l}\text { North } \\
\text { America }\end{array}$ & $\begin{array}{l}67 \\
\text { (all male) } \\
37 \text { athletes } \\
\text { and } 30 \\
\text { singing } \\
\text { group } \\
\text { memoers }\end{array}$ & $\begin{array}{l}\text { Ice hockey, } \\
\text { intercollegiate } \\
\text { level }\end{array}$ & $\begin{array}{l}\text { Quantitative, } \\
\text { experimental, } \\
\text { cross-sectional }\end{array}$ & Indirectly & Indirectly & $\begin{array}{l}\text { Student-athletes had } \\
\text { significantly lower GPA than } \\
\text { non-athletes. Priming student- } \\
\text { athletes with their athletic } \\
\text { identity decreased academic } \\
\text { self-regard, and academic task } \\
\text { perrormance compared to non- } \\
\text { athletes }\end{array}$ \\
\hline
\end{tabular}


may internalize these stereotypes, which may have subsequent negative implications for their academic performance (see Bimper, 2014).

\section{Directions for Future Research}

Methodological recommendations. Firstly, all but three of the studies in this review were conducted cross-sectionally; subsequently, there is not yet a clear picture of the causal relationship between the development of academic and athletic identities and their relationships with wellbeing and performance outcomes. Future investigations of academic and athletic identities are encouraged to use within-person longitudinal modelling to explore the dynamic nature of self-identities, and how the relative importance of key self-identities change over time in response to changing task and role demands.

Secondly, there appears to be no gold standard for measuring academic and athletic identities (see Guidotti et al., 2015). Despite recent concern as to psychometric validity of the AIMS, relating to discrepancies in item factor loadings (Burns, Jasinski, Dunn, \& Fletcher, 2012), one third of the quantitative studies in this review used this measure of athletic identity. Findings of this review suggesting that student-athletes may simultaneously develop salient academic and athletic identities, indicates that the measurement of these identities on a sliding scale (per Antshel et al., 2016), may not have an empirical basis as they fail to align with our theoretical understanding of relational identities as linked to key (often multiple) life roles (Stets \& Burke, 2000). Additionally, a single item is unlikely to be sufficient when measuring the complexities of self-definition (Rafaeli-Mor, Gotlib, \& Revelle, 1998). Yukhymenko-Lescroart (2014) has addressed these concerns by developing the AAIS, which has promising psychometric properties. We encourage future research to examine the cross-cultural psychometric validity of the AAIS as it could become a gold standard in dual career research.

This review narrowly focused on the academic and athletic identities of student-athletes. Although these identities are proposed to represent salient identities for this sample, future researchers are encouraged to consider the wider context and intersectionality of other important identities, such as identities as a female, atheist, and heterosexual, and roles beyond the university context such as employee, spouse, and parent (Caza et al., 2018).

Finally, research investigating academic and athletic identities has, perhaps logically, used samples of student-athletes who are currently engaged in dual careers. However, this methodology may inherently cause a survivor bias (Smith, 2014), where characteristics of those remaining in dual careers are interpreted as their reasons for pursuing dual careers. We would recommend researchers investigate the academic and athletic identities of not only those retained in dual careers, but also those who decide to drop out of education to focus on sport or vice versa, investigating reasons leading to departure decisions.

Context recommendations. This review has revealed that $52 \%$ of the contemporary literature on the identities of student-athletes has been conducted in the North American collegiate context, primarily in NCAA colleges. We may expect that the 
structural differences between the NCAA and systems existing beyond North America, may have a significant influence on student-athletes' identity development, role conflict and wellbeing, and career development (Ryba, Stambulova, Ronkainen, Bundgaard, \& Selänne, 2015). For instance, in contexts where elite sports are not integrated within the formal university systems, decisions to pursue an education are likely to be made autonomously, based on a genuine interest in furthering one's education. Hence student-athletes operating outside of the NCAA may be more intrinsically motivated to pursue education and in exploring self-identities beyond sport. Subsequently, it is proposed that academic and athletic identities may be more intertwined among NCAA student-athletes, while greater separation of the athletic and academic identities may be prevalent among student-athletes in non-NCAA systems. Subsequently, we recommend future research targets student-athletes outside of the NCAA system, so that these contextual differences can be explored.

We also encourage future research to explore how context may influence negative stereotyping of student-athletes. The degree to which negative athlete stereotyping occurs in academic settings outside of North America is largely unknown and is a matter for further investigation. Further, researchers are encouraged to expand upon the work of Chen and colleagues (2010) and explore positive self-perceptions and positive stereotypes associated with student-athletic roles, and whether cross-cultural differences exist in these perceptions.

\section{Implications}

Understanding identity development in student-athletes will better equip universities and sports practitioners in supporting athletic development initiatives. NCAA institutions have greater authority than other universities to make sporting participation contingent upon student-athlete class attendance and achievement of minimum GPAs, as well as increased ability to reduce scheduling conflicts between sporting and academic events (Ridpath, 2008). However, there are several ways that all universities may assist student-athletes in reducing role demands. Because attending mandatory classes was identified as an obstacle for student-athletes especially during times of sporting competition, providing flexibility to change between allocated class times or offering external or online courses may increase academic engagement (see Brown et al., 2015). Student-athletes may also benefit from flexibility regarding minimum course duration (Brown et al., 2015; Fuches et al., 2016). University athlete assistance programs may be useful in helping student-athletes develop strategies for better managing their time, and for liaising between the university and the student for seeking academic flexibility. Given that this review has also identified career planning as important for facilitating successful career transitions out of sport, access to career planning resources is likely to be important in fostering student-athletes to develop professional self-identities beyond sport. 


\section{Conclusion}

In conclusion, in surveying available literature relating to the academic and athletic identities of student-athletes, this review identified and interpreted 42 studies simultaneously exploring these identities. Results revealed that contemporary research on the self-identities of student-athletes has focused on: the development of academic and athletic identities through university, role conflict between dual careers and the influence on wellbeing, career motivation and maturity, and stereotype threats to student-athletes. The findings suggest that student-athletes develop academic identities, albeit these are likely to be less important to their self-definition compared to their athletic identities, particularly in earlier university years. Many student-athletes report awareness of the limited timeframe of participation in elite sports and pursue academics to foster their post-sporting careers and to facilitate a successful transition out of sports.

Considerations for future research were examined, and importantly it was proposed that future research consider the influence of differences in national talent development systems on the development of academic and athletic identities. It is important that dual career research is better able to delineate how academic and athletic identities develop in student-athletes, and how these processes affect psychological wellbeing and performance outcomes. A better understanding of these processes will inform policy and practice among sporting organizations, universities, and sports psychologists to facilitate the performance and wellbeing of student-athletes in education and sport.

\section{References}

Anderson, D. (2012). A balanced approach to excellence: Life-skill intervention and elite performance. Reflective Practice, 13, 609-620.

*Antshel, K. M., VanderDrift, L. E., \& Pauline, J. S. (2016). The role of athletic identity in the relationship between difficulty thinking or concentrating and academic service use in NCAA student-athletes. Journal of Clinical Sport Psychology, 10, 309-323.

*Aquilina, D. (2013). A study of the relationship between Elite Athletes' educational development and sporting performance. International Journal of the History of Sport, 30, 374-392.

Ashforth, B. E., Harrison, S. H., \& Corley, K. G. (2008). Identification inorganizations: An examination of four fundamental questions. Journal of Management, $34,325-374$

*Beron, K. J., \& Piquero, A. R. (2016). Studying the determinants of student-athlete grade point average: The roles of identity, context, and academic interests. Social Science Quarterly, 97, 142-160.

*Bimper, A. Y. (2014). Game changers: The role athletic identity and racial identity play on academic performance. Journal of College Student Development, 55, 805-807. 
*Blodgett, A. T., \& Schinke, R. J. (2015). "When you're coming from the reserve you're not supposed to make it": Stories of Aboriginal athletes pursuing sport and academic careers in "mainstream" cultural contexts. Psychology of Sport and Exercise, 21, 115-124.

Brewer, B. W., Cornelius, A. E., Stephan, Y., \& Van Raalte, J. L. (2009). Self-protective changes in athletic identity following anterior cruciate ligament reconstruction. Psychology of Sport and Exercise, 11, 1-5.

Brewer, M. B., \& Gardner, W. (1996). Who is this "We"? Levels of collective identity and self representations. Journal of Personality and Social Psychology, 71, 83-9

Brewer, B W., \& Petitpas, A. J. (2017). Athletic identity foreclosure. Current Opinion in Psychology, 16, 118-122.

Brewer, B. W., Selby, C. L., Linder, D E., \& Petitpas, A. J. (1999) Distancing oneself from a poor season: Divestment of athletic identity. Journal of Personal and Interpersonal Loss, 4, 149-162.

Brewer, B. W., Van Raalte, J. L., \& Linder, D. E. (1993). Athletic identity: Hercules' muscles or Achilles heel? International Journal of Sport Psychology, 24, 237 254.

*Brown, D. J., Fletcher, D., Henry, I., Borrie, A., Emmett, J., Buzza, A., \& Wombwell, S. (2015). A British university case study of the transitional experience of student-athletes. Psychology of Sport and Exercise, 21, 78-90.

Brown, C., \& Hartley, D. L. (1998). Athletic identity and career maturity of male college student athletes. International Journal of Sport Psychology, 29, 17-26.

Brown, G., \& Potrac, P. (2009). 'You've not made the grade, son': De-selection and identity disruption in elite level youth football. Soccer \& Society, 10, 143-159.

Burke, P.J., \& Stets, J. E. (2009). Identity theory. New York, NY: Oxford University Press

Burns, G. N., Jasinski, G., Dunn, S. C., \& Fletcher, D. (2012). Athlete identity and athlete satisfaction: The nonconformity of exclusivity. Personality and Individuals Differences, 52, 280-284.

Caza, B. B., Vough, H., \& Puranik, H. (2018). Identity work in organizations and occupations: Definitions, theories, and pathways forward. Journal of Organizational Behavior, 39, 889-910.

Chen, S., Snyder, S., \& Magner, M. (2010). The effects of sport participation on student-athletes' and non-athlete students' social life and identity. Journal of Issues in Intercollegiate Athletics, 3, 176-193.

Cooper, J. N. (2012). Personal troubles and public issues: A sociological imagination of black athletes' experiences at predominately white institutions in the United States. Sociology Mind, 2, 261-271.

Cummins, P., \& O’Boyle, I. (2015). Psychosocial factors involved in transitions from college to postcollege careers for male NCAA division-I basketball players. Journal of Career Development, 42, 33-47.

DeCandia, G. M. (2014). Relationship between academic identity and academic 
achievement in low-income urban adolescents (Unpublished doctoral dissertation). The State University of New Jersey.

*Erpič, S. C., Wylleman, P., \& Zupančič, M. (2004). The effect of athletic and non-athletic factors on the sports career termination process. Psychology of Sport and Exercise, 5, 45-59.

Ewing, D. R., \& Allen, C. T. (2017). Self-congruence is not everything for a brand: Initial evidence supporting the relevance of identity cultivation in a college student role-identity content. Journal of Brand Management, 24, 405-422.

*Falls, D., \& Wilson, B. (2013). 'Reflexive modernity' and the transition experiences of university athletes. International Review for the Sociology of Sport, 48, 572593.

*Feltz, D. L., Schneider, R., Hwang, S., \& Skogsberg, N. J. (2013). Predictors of collegiate student-athletes' susceptibility to stereotype threat. Journal of College Student Development, 54, 184-201

*Foster, S. J. L., \& Huml, M. R. (2017). The relationship between athletic identity and academic major chosen by student-athletes. International Journal of Exercise Science, 10, 915-925.

*Fuches, P. X. Wagner, H., Hannola, H., Niemisalo, N., Pehme, A., Puhke, R., Marinsek, M., Strmecki, A., Svetec, D., Capranica, L., \& Guidotti, F. (2016). European student-athletes' perceptions on dual career outcomes and services. Kinesiologia Slovenica, 22, 31-48.

Fuller, R. D. (2014). Transition experiences out of intercollegiate athletics: A meta-synthesis. The Qualitative Report, 19, 1-15.

Gecas, V. (1982). The self-concept. Annual Review of Sociology, 8, 1-33.

*Geraniosova, K., \& Ronkainen, N. (2014). The experience of dual career through Slovak athletes' eyes. Physical Culture and Sport: Studies and Research, 66, 53-64.

Green, S. L., \& Weinberg, R. S. (2001). Relationships among athletic identity, coping skills, social support, and the psychological impact of injury in recreational participants. Journal of Applied Sport Psychology, 13, 40-59.

Grove, J. R., Lavallee, D., \& Gordon, S. (1997). Coping with retirement from sport: The influence of athletic identity. Journal of Applied Sport Psychology, 9, 191203.

Guidotti, F., Cortis, C., \& Capranica, L. (2015). Dual career of European student-athletes: A systematic literature review. Kinesiologia Slovenica, 21, 5-20.

*Harrison, C. K, \& Lawrence, S. M. (2004). Female and male student athletes' perceptions of career transition in sport and higher education: A visual elicitation and qualitative assessment. Journal of Vocational Education and Training, 56, 485-506

Hatch, J. (2002). Doing qualitative research in education settings. Albany, NY: State University of New York Press.

Hawkins, M. R. (2005). Becoming a student: Identity work and academic literacies in early schooling. TESOL Quarterly, 39, 59-82.

*Hawley, L. R., Hosch, H. M., \& Bovaird, J. A. (2014). Exploring social identity the- 
ory and the 'black sheep effect' among college student-athletes and non-athletes. Journal of Sport Behavior, 37, 56-76.

*Healy, L., Ntoumanis, N., \& Duda, J. (2016). Goal motives and multiple-goal striving in sport and academia: A person-centered investigation of goal motives and inter-goal relations. Journal of Science and Medicine in Sport, 19, 1010-1014.

Hejazi, E., Lavasani, M. G., Amani, H., \& Was, C. A. (2012). Academic identity status, goal orientation, and academic achievement among high school students. Journal of Research in Education, 22, 292-320.

Henriksen, K., Stambulova, N., \& Roessler, K. K. (2010). Holistic approach to athletic talent development environments: A successful sailing milieu. Psychology of Sport and Exercise, 11, 212-222.

Horton, R. S., \& Mack, D. E. (2000). Athletic identity in marathon runners: Functional focus or dysfunctional commitment? Journal of Sport Behavior, 23, 101119.

Houle, J. L. W., Brewer, B. W., \& Kluck, A. S. (2010). Developmental trends in athletic identity: A two-part retrospective study. Journal of Sport Behavior, 33, 146-159.

*Huang, C., Chou, C., \& Hung, T. (2016). College experiences and career barriers among semi-professional student-athletes: The influences of athletic identity and career self-efficacy. The Career Development International, 21, 571-586.

Ivarsson, A., Stenling, A., Fallby, J., Johnson, U., Borg, E., \& Johansson, G. (2015). The predictive ability of the talent development environment on youth elite football players' wellbeing: A person-centered approach. Psychology of Sport and Exercise, 16, 15-23.

Kaplan, A., \& Flum, H. (2010). Achievement goal orientations and identity formation styles. Educational Research Review, 5, 50-67.

*Killeya-Jones, L. (2005). Identity structure, role discrepancy and psychological adjustment in male college student-athletes. Journal of Sport Behavior, 28, 167185.

*Kimball, A. C. (2007). "You signed the line": Collegiate student-athletes' perceptions of autonomy. Psychology of Sport and Exercise, 8, 818-835.

Lairio, M., Puukari, S., \& Kouvo, A. (2013). Studying at university as part of student life and identity construction. Scandinavian Journal of Educational Research, 57, 115-131.

*Lally, P. (2007). Identity and athletic retirement: A prospective study. Psychology of Sport and Exercise, 8, 85-99.

*Lally, P. S., \& Kerr, G. A. (2005). The career planning, athletic identity, and student role identity of intercollegiate student athletes. Research Quarterly for Exercise and Sport, 76, 275-285.

Lantz, C. D., \& Schroeder, P. J. (1999). Endorsement of masculine and feminine gender roles: Differences between participation in and identification with the athletic role. Journal of Sport Behavior, 22, 545-557.

Li, M., \& Sum, R. K. W. (2017). A meta-synthesis of elite athletes' experiences in 
dual career development. Asia Pacific Journal of Sport and Social Science, 6, 99-17.

Linville, P. W. (1985). Self-complexity and affective extremity: Don't put all of your eggs in one cognitive basket. Social Cognition, 3, 94-120.

*López de Subijana, C., Barriopedro, M., \& Sanz, I. (2015). Dual career motivation and identity on elite athletes. Revista de Psicologia del Deporte, 24, 55-57.

*Lupo, C., Guidotti, F., Goncalves, C., Moreira, L., Doupona-Topic, M., Bellardini, H., Tonkonogi, M., Colin, A., \& Capranica, L. (2015). Motivation towards dual career of European student-athletes. European Journal of Sport Science, 15, 151-160.

*Lupo, C., Mosso, C. O., Guidotti, F., Cugliari, G., Pizzigalli, L., \& Rainoldi, A. (2017a). The adapted Italian version of the baller identity measurement scale to evaluate the student-Athletes' identity in relation to gender, age, type of sport, and competition level. PLoS One, 12, 1-11.

*Lupo, C., Mosso, C. O., Guidotti, F., Cugliari, G., Pizzigalli, L., \& Rainoldi, A. (2017b). Motivation toward dual career of Italian student-athletes enrolled in different university paths. Sport Sciences for Health, 13, 485-494.

*Lupo, C., Tessitore, A., Capranica, L., Rauter, S., \& Doupona-Topic, M. (2012). Motivation for a dual career: Italian and Slovenian student-athletes. Kinesiologia Slovenica, 18, 47-56.

*Melendez, M. C. (2009). Psychosocial influences on college adjustment in Division 1 student-athletes: The role of athletic identity. Journal of College Student Retention: Research, Theory and Practice, 11, 345-361.

*Mignano, A. C., Brewer, B. W., Winter, C., \& Van Raalte, J. L. (2006). Athletic identity and student involvement of female athletes at NCAA Division III women's and coeducational colleges. Journal of College Student Development, 47, 457-464.

*Miller, P. S., \& Kerr, G. A. (2003). The role experimentation of intercollegiate student athletes. The Sport Psychologist, 17, 196-219.

Moher, D., Liberati, A., Tetzlaff, J., \& Altman, D. G: The PRISMA Group. (2009). Preferred reporting items for systematic reviews and meta-analyses: The PRISMA Statement. PloS Medicine, e1000097. http:doi.org/10.1371/journal. pmed.1000097

Mortimer, J. T., Lam, J., \& Lee, S-R. (2015). Transformation, erosion, or disparity in work identity? Challenges during the contemporary transition to adulthood. In K. C. McLean \& M. Syed (Eds). The Oxford handbook of identity development (pp. 319-336). New York, NY: Oxford University Press.

Osborne, J. W., \& Jones, B. D. (2011). Identification with academics and motivation to achieve in school: How the structure of the self influences academic outcomes. Educational Psychology Review, 23, 131-158.

Rafaeli-Mor, E., Gotlib, I. H., \& Revelle, W. (1999). The meaning and measurement of self-complexity. Personality and Individual Differences, 27, 341-356.

Reifsteck, E. J., Gill, D. L. \& Labban, J. D. (2016). 'Athletes' and 'exercisers': Un- 
derstanding identity, motivation, and physical activity. Sport, Exercise, and Performance Psychology, 5, 25-38.

*Riciputi, S., \& Erdal, K. (2017). The effect of stereotype threat on student-athlete math performance. Psychology of Sport and Exercise, 32, 54-57.

Ridpath, B. D. (2008). Can the faculty reform intercollegiate athletics? A part, present, and future perspective. Journal of Issues in Intercollegiate Athletics, 1, 1125.

Ronkainen, N. J., Kavoura, A., \& Ryba, T. V. (2016). A meta-study of athletic identity research in sport psychology: Current status and future directions. International Review of Sport and Exercise Psychology, 9, 45-64.

Ryba, T. V., Stambulova, N. B., Ronkainen, N. J., Bundgaard, J., \& Selänne, H. (2015). Dual career pathways of transnational athletes. Psychology of Sport and Exercise, 21, 125-134.

Schinke, R. J., Stambulova, N. B., Si, G., \& Moore, Z. (2018). International society of sport psychology position stand: Athletes' mental health, performance, and development. International Journal of Sport and Exercise Psychology, 16, 622639.

Schulz, R., \& Heckhausen, J. (1996). A life span model of successful aging. American Psychologist, 51, 702-714.

*Settles, I. H., Sellers, R. M., \& Damas, A., Jr. (2002). One role or two? The function of psychological separation in role conflict. Journal of Applied Psychology, 87, 574-582. http:doi.org/10.1037/0021-9010.87.3.574

Simon, H. D. Bosworth, C., Fujita, S., \& Jensen, M. (2007). The athlete stigma in higher education. College Student Journal, 41, 251-273.

Skaalvik, E., \& Skaalvik, S. (2002). Internal and external frames of reference of academic self-concept. Educational Psychologist, 37, 233-244.

Smith, G. (2014). Standard deviations: Flawed assumptions, tortured data, and other ways to lie with statistics. London: Duckworth.

Smith, A. B., \& Hardin, R. (2018). Female student-athletes' transition out of collegiate competition. Journal of Amateur Sport, 4, 61-86.

Stambulova, N. B., Engström, C., Franck, A., Linnér, L., \& Lindahl, K. (2015). Searching for an optimal balance: Dual career experiences of Swedish adolescent athletes. Psychology of Sport and Exercise, 21, 4-14.

Stambulova, N. B., Stephan, Y., \& Japhag, U. (2007). Athletic retirement: A cross-national comparison of elite French and Swedish athletes. Psychology of Sport and Exercise, 8, 101-118.

Stambulova, N., \& Wylleman, P. (Eds.). (2015). Dual career development and transitions (special issue). Psychology of Sport and Exercise, 21, 1-134.

Stambulova, N. B., \& Wylleman, P. (2019). Psychology of athletes' dual careers: A state-of-the-art critical review of the Europeans discourse. Psychology of Sport \& Exercise, 42, 74-88.

Stets, J. E., \& Burke, P. J. (2000). Identity theory and social identity theory. Social Psychology Quarterly, 63, 224-237

*Stoltenburg, A. L., Kamphoff, C. S., \& Bremer, K. L. (2011). Transitioning out 
of sport: The psychosocial effects of collegiate athletes' career-ending injuries. Athletic Insight, 13, 1-11.

*Stone, J., Harrison, C. K., \& Mottley, J. (2012). 'Don't call me a student-athlete': The effect of identity priming on stereotype threat for academically engaged African American college athletes. Basic and Applied Social Psychology, 34, 99-106.

*Sturm, J. E., Feltz, D.L., \& Gilson, T.A. (2011). A comparison of athlete and student identity for Division I and Division III athletes. Journal of Sport Behavior, 34, 295-306.

Stryker, S. (1987). Identity theory: developments and extensions. In K. Yardley, \& T. Hones (Eds.), Self and identity: Psychosocial perspectives (pp. 83-103). New York, NY: Wiley.

Stryker, S., \& Burke, P. J. (2000). The past, present, and future of an identity theory. Social Psychology Quarterly, 63, 284-297.

*Sum, R. W., Tsai, H-H., Ha, A. S. C., Cheng, C., Wang, F., \& Li, M. (2017). Social-ecological determinants of elite student athletes' dual career development in Hong Kong and Taiwan, Sage Open, 7, 1-12.

Swanson, D., Spencer, M., Dell'Angelo, T., Harpalani, V., \& Spencer, T. R. (2002). Identity processes and the positive youth development of African Americans: An explanatory framework. New Directions for Youth Development, 95, 73-99.

*Tekavc, J., Wylleman, P., \& Erpič, S. C. (2015). Perceptions of dual career development among elite level swimmers and basketball players. Psychology of Sport and Exercise, 21, 27-41.

Terry, D. J., Hogg, M. A., \& White, K. M. (1999). The theory of planned behaviour: Self-identity, social identity and group norms. British Journal of Social Psychology, 38, 225-244

Thoits, P. A. (1983). Multiple identities and psychological well-being: A reformulation and test of the social isolation hypothesis. American Sociological Review, 48, 174-187.

*Torregrosa, M., Ramis, Y., Pallarés, S., Azócar, F., \& Selva, C. (2015). Olympic athletes back to retirement: A qualitative longitudinal study. Psychology of Sport and Exercise, 21, 50-56.

*Tshube, T., \& Feltz, D.L. (2015). The relationship between dual-career and postsport career transition among elite athletes in South Africa, Botswana, Namibia and Zimbabwe. Psychology of Sport \& Exercise, 21, 109-114.

van Rens, F. E. C. A., Borkoles, E., Farrow, D., Curran, T., \& Polman, R. C. (2016). Development and initial validation of the Role Strain Questionnaire for Junior Athletes (RSQ-JA). Psychology of Sport and Exercise, 24, 168-178.

*van Rens, F. E. C. A., Ashley, R. A., \& Steele, A. R. (2019). Wellbeing and performance in dual careers: The role of academic and athletic identities. The Sport Psychologist, 33, 42-51

Williams, J. M., \& Krane, V. (1993). Psychological characteristics of peak perfor- 
mance. In J. M. Williams (Ed.), Applied Sport Psychology (2nd ed., pp. 137147). Mountain View, CA: Mayfield.

*Woodruff, A. L., \& Schallert, D. L. (2008). Studying to play, playing to study: Nine college student-athletes' motivational sense of self. Contemporary Educational Psychology, 33, 34-57.

Wylleman, P., \& Lavallee, D. (2004). A developmental perspective on transitions faced by athletes. In M. R. Weiss (Ed.), Developmental Sport and Exercise Psychology: A Lifespan Perspective (pp. 507-527). Morgantown, WV: Fitness Information Technology.

Wylleman, P., \& Rosier, N. (2016). Holistic perspective on the development of elite athletes. In M. Raab, P. Wylleman, R. Seiler, A.-M. Elbe, \& A. Hatzigeorgiadis (Eds.), Sport and Exercise Psychology Research (pp. 269-288). London: Elsevier Academic Press.

Wylleman, P., Rosier, N., \& De Knop, P. (2015). Transitional challenges and elite athletes' mental health. In J. Baker, P. Safai, \& J. Fraser-Thomas (Eds.), Health and elite sport. Is high performance sport a healthy pursuit? (pp. 99-116). Research in Sport, Culture and Society; Vol. 38). New York, NY; Routledge.

*Yopyk, D. J. A., \& Prentice, D. A. (2005). Am I an athlete or a student? Identity salience and stereotype threat in student-athletes. Basic and Applied Social Psychology, 27, 329-336.

*Yukhymenko-Lescroart, M. A. (2014). Students and athletes? Development of the Academic and Athletic Identity Scale (AAIS). Sport, Exercise, and Performance Psychology, 3, 89-101.

*Yukhymenko-Lescroart, M. A. (2018). On identity and sport conduct of student athletes: Considering athletic and academic contexts. Psychology of Sport and Exercise, 34, 10-19.

Note: * indicates references included in the review 